Article

\title{
Evaluation of the Radar Speed Cameras and Panels Indicating the Vehicles' Speed as Traffic Calming Measures (TCM) in Short Length Urban Areas Located along Rural Roads
}

\author{
Heriberto Pérez-Acebo ${ }^{1, *(\mathbb{D})}$, Robert Ziolkowski ${ }^{2} \mathbb{D}$ and Hernán Gonzalo-Orden ${ }^{3}$ (D) \\ 1 Mechanical Engineering Department, University of the Basque Country UPV/EHU, $\mathrm{P}^{\circ}$ Rafael Moreno \\ Pitxitxi, 2, 48013 Bilbao, Spain \\ 2 Faculty of Civil and Environmental Sciences, Bialystok University of Technology, Wiejska 45A, \\ 15-351 Bialystok, Poland; robert.ziolkowski@pb.edu.pl \\ 3 Department of Civil Engineering, University of Burgos, c/Villadiego, s/n, 09001 Burgos, Spain; \\ hgonzalo@ubu.es \\ * Correspondence: heriberto.perez@ehu.eus; Tel.: +34-94-601-7820
}

Citation: Pérez-Acebo, H.;

Ziolkowski, R.; Gonzalo-Orden, H.

Evaluation of the Radar Speed

Cameras and Panels Indicating the

Vehicles' Speed as Traffic Calming

Measures (TCM) in Short Length

Urban Areas Located along Rural

Roads. Energies 2021, 14, 8146.

https://doi.org/10.3390/en14238146

\section{Academic Editors:}

Elżbieta Macioszek, Anna Granà,

Margarida Coelho and

Paulo Fernandes

Received: 10 November 2021

Accepted: 30 November 2021

Published: 5 December 2021

Publisher's Note: MDPI stays neutral with regard to jurisdictional claims in published maps and institutional affiliations.

Copyright: (c) 2021 by the authors. Licensee MDPI, Basel, Switzerland. This article is an open access article distributed under the terms and conditions of the Creative Commons Attribution (CC BY) license (https:/ / creativecommons.org/licenses/by/ $4.0 /)$.

\begin{abstract}
Traffic calming measures (TCMs) are implemented in urban areas to reduce vehicles' speed and, generally speaking, results are obtained. However, speed is still a problem in rural roads crossing small villages without a bypass and with short-length urban areas, since drivers do not normally reduce their speed for that short segment. Hence, various TCM can be installed. It is necessary to maintain a calm area in these short segments to improve road safety, especially for pedestrian aiming to cross the road, and to save combustible by avoiding a constant increase-decrease of speed. Four villages were selected to evaluate the efficiency of radar speed cameras and panels indicating vehicle's speed. Results showed that the presence of radar speed cameras reduces the speed in the direction they can fine, but with a lower effect in the non-fining direction. Additionally, a positive effect was observed in the fining direction in other points, such as pedestrian crossings. Nevertheless, the effect does not last long and speed cameras may be considered as punctual measures. If the TCMs are placed far from the start of the village they are not respected. Hence, it is recommended to place them near the real start of the build-up area. Lastly, it was verified that longer urban areas make overall speed decrease. However, when drivers feel that they are arriving to the end of the urban area, due to the inexistence of buildings, they start speeding up.
\end{abstract}

Keywords: traffic calming measure; radar speed camera; urban area; road safety; rural roads; pedestrian; crosswalk

\section{Introduction}

Despite the great efforts that have been carried out to reduce the number of fatalities and injuries on road crashes, road safety continues to be a major problem around the world, even becoming the first cause of premature death [1,2]. Some figures could give an approximate idea about this reality. In the European Union (EU-27), there were 935,216 crashes resulting in injuries or death in 2019, which represents a low reduction of $3.9 \%$ from 2010, with 973,596. Some countries such as Spain and Romania registered an increase of 20\% in the number of crashes during this period (2010-2019) [3]. Nevertheless, talking about fatalities, 22,700 people died in 2019, showing a decrease of $23.3 \%$ with regard to data from 2010, with 29,611 deaths. The only country with an increase of fatalities between 2010 and 2019 was the Netherlands [3]. In relative figures, the EU-27 reported a decrease from 67 fatalities per million inhabitants in 2010 to 51 in $2019(-23 \%)$ but this positive trend in fatalities reduction has been distinctly flattened in last few years [3].

Nonetheless, it must be noted that one out of five $(20.4 \%)$ of all road fatalities in the EU-27 are pedestrians, representing a higher proportion than other vulnerable road users 
(cyclist, 9\%; mopeds, 3\%; motorcycles 15\%) [4,5]. Despite the fall in pedestrian fatalities from 2010 (5952) to 2018 (4763), implying a reduction of $20 \%$, this figure is even lower to the global decrease of fatalities mentioned before $(-23.3 \%$ for all the fatalities) and, hence, the proportion of pedestrians in total number of road fatalities remains constant (or even slightly higher). Individual data from Poland and Spain are shown in Table 1. As seen, both countries reported decreases in the number of fatalities, in pedestrian fatalities, and in the ratio fatalities per million inhabitants. However, the overall proportion of pedestrians killed in crashes is quite different. While it ranged from 31.6\% to 27.3\% in Poland, in Spain it is around $20 \%$.

Table 1. Road safety data from Poland and Spain in 2010 and in 2019.

\begin{tabular}{|c|c|c|c|c|c|c|c|c|c|c|c|c|}
\hline \multirow[b]{2}{*}{ Country } & \multicolumn{3}{|c|}{$\begin{array}{c}\text { Total Number of Road } \\
\text { Crashes }\end{array}$} & \multicolumn{3}{|c|}{$\begin{array}{l}\text { Total Number of } \\
\text { Fatalities }\end{array}$} & \multicolumn{3}{|c|}{ Fatalities Per Million } & \multicolumn{3}{|c|}{ Pedestrian Fatalities } \\
\hline & 2010 & 2019 & $\begin{array}{l}\text { Change } \\
(\%)\end{array}$ & 2010 & 2019 & $\begin{array}{l}\text { Change } \\
\text { (\%) }\end{array}$ & 2010 & 2019 & $\begin{array}{l}\text { Change } \\
\qquad \%)\end{array}$ & $\begin{array}{l}2010(\% \text { of } \\
\text { the Total) }\end{array}$ & $\begin{array}{c}2019(\% \text { of } \\
\text { the Total) }\end{array}$ & $\begin{array}{c}\text { Change } \\
(\%)\end{array}$ \\
\hline Poland & 38,832 & 30,288 & -22.0 & 3908 & 2909 & -25.6 & 103 & 77 & -25.2 & $1236(31.6)$ & 793 (27.3) & -35.8 \\
\hline Spain & 85,503 & 104,080 & +21.7 & 2479 & 1755 & -29.2 & 53 & 37 & -30.2 & $471(19.0)$ & 381 (21.7) & -19.1 \\
\hline
\end{tabular}

Traditionally, road crashes are said to be multi-causal, which are generally grouped in factors related to driver, vehicle, and highway conditions [6-8], with variable proportions (Figure 1) [9].

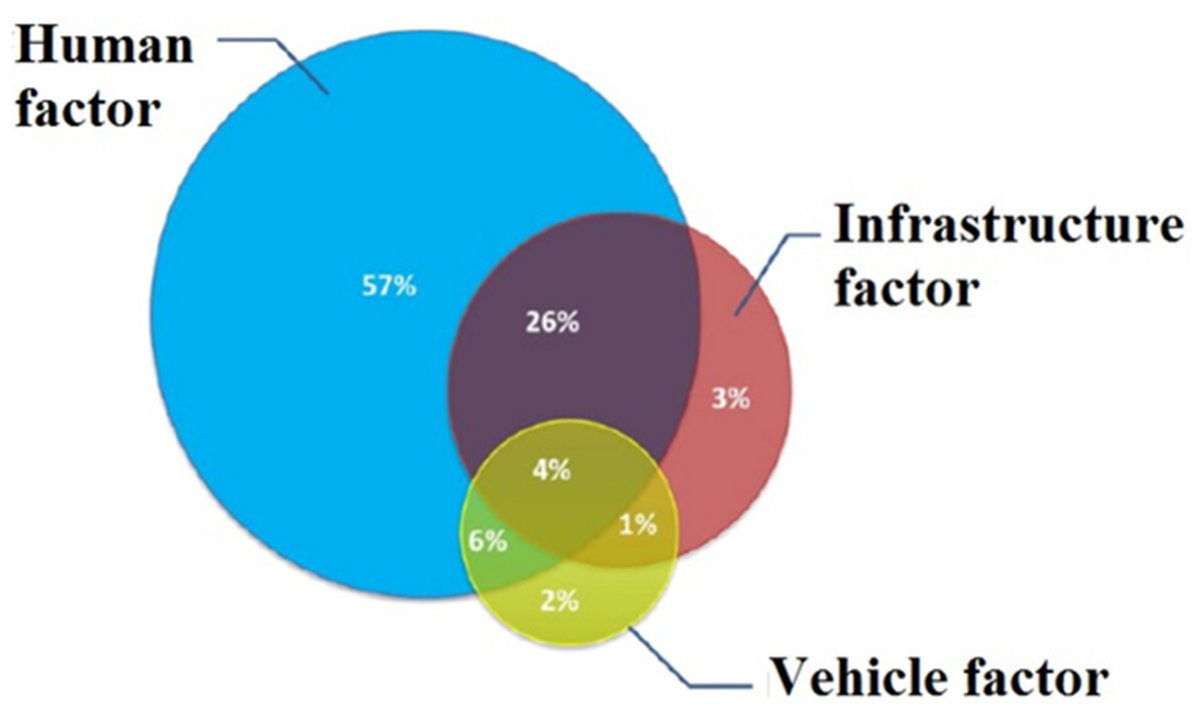

Figure 1. Interaction of the concurrent factors on road crashes.

Nevertheless, speed is said to be the key factor in serious and fatal crashes involving pedestrians, with a great influence on injury severity of pedestrians $[5,10]$. When vehicles travel below $30 \mathrm{~km} / \mathrm{h}$, the collisions between motorized vehicles and pedestrians are much less likely to happen, and if they occur, they do not normally result in fatality [10]. Correlations between the risk of pedestrian fatality and the speed impact have been established (Figure 2) [11]. 


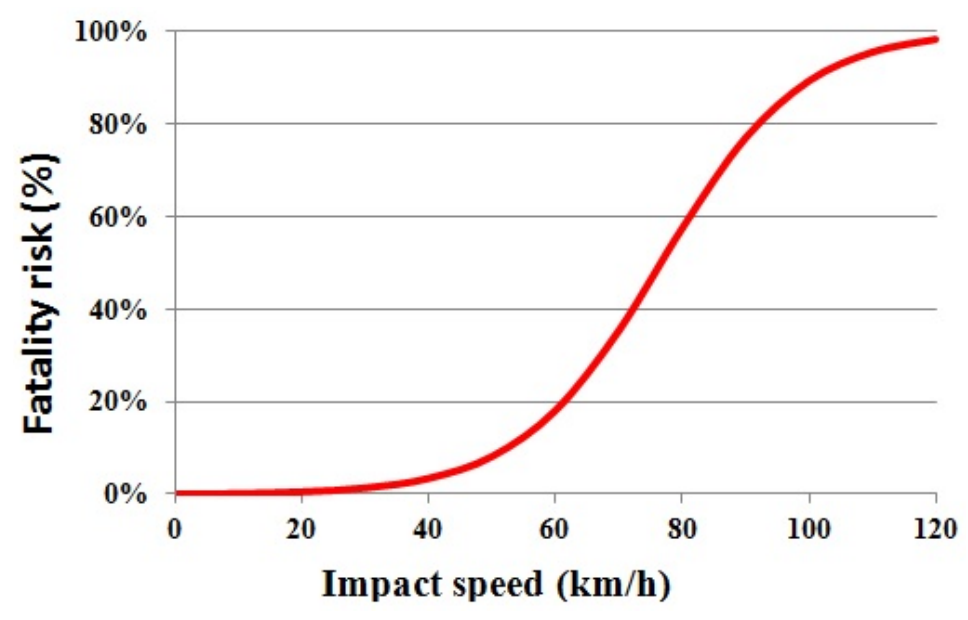

Figure 2. Risk of pedestrian fatality for different impact speeds (fatality rate is the percentage of pedestrians that are killed in a collision with a motorized vehicle).

In European countries, as expected, urban areas are the location where the majority of pedestrian fatalities occur $(73 \%)$, increasing the relative percentage of the pedestrian death to the total deaths up to $38 \%$ (as previously said, pedestrian fatalities represent the $20 \%$ of the total). In Poland and in Spain, the proportion of pedestrians killed in urban areas represents $64.3 \%$ and $64.8 \%$, respectively [3]. It has been reported that approximately two thirds of pedestrians involved in server road crashes were crossing the road [12]. Yue et al. [13] identified the main scenarios for fatal pedestrian crashes in Florida, indicating the percentage of occurrence:

- Vehicle going straight and pedestrian crossing the road (51\%);

- Vehicle turning left and pedestrian crossing the road at the exit $(17 \%)$ or the entry $(3 \%)$ of the crossing;

- Vehicle turning right and pedestrian crossing the road at the exit $(12 \%)$ or the entry (4\%) of the crossing;

- Vehicle going straight and pedestrian in $(3 \%)$ or adjacent to $(6 \%)$ the road.

Similarly, Populer et al. [14] identified the most frequent scenarios for pedestrian crossing crashes and observed that the main contributing factors for signal-regulated crossing were non-compliance by the pedestrian $(50 \%)$ and conflicting green-phases for pedestrians and turning motorists $(25 \%)$. In non-signalized crossing, obstruction of view due to other traffic actors or parked vehicles was concluded to be the main factor [15]. Furthermore, the majority of accidents in Poland is reported in urban areas and driving speed remains the most important factor According to the International Transport Forum [16], unadjusted and excessive speed is the main cause of one third of all fatal road crashes in Hungary, Poland, and Lithuania. Equal conclusions emerged from official statistics published in Poland by the Police Headquarters [17].

With the aim of minimizing the vehicles' speed, traffic calming measures (TCM) have been introduced in urban areas [18-21]. They are usually defined as "the combination of mainly physical measures that reduce the negative effect of motor vehicle use, alter driver behavior and improve conditions for non-motorized street users" [22]. Their main goal is thus to reduce vehicle speed and volume in the area. Generally, TCMs are classified in four categories: vertical deflections (rumble strips, speed humps, speed cushions, raised crosswalk, raised intersection, etc.), horizontal deflections (chicane, gateway, raised median island, etc.); physical obstructions (semi and diagonal diverter, raised median in intersections, etc.); and sings and pavement markings (a meter) [23-34].

With regard to the environment, an important point to consider is fuel consumption and car emissions as a result of the driving speed and style in urban areas. Generally speaking, lower average speeds and higher number of stops are the main characteristics of driving in urban areas, implying both fuel consumption and pollutant emissions many 
times higher per vehicle $\mathrm{km}$. The effect of speed humps and speed tables on the pollutant emissions was analyzed by Obregón-Biosca [35]. Similarly, other authors evaluated the exhaust emissions and fuel consumption on Tempo-30-zoned streets [36,37]. However, it was reported that the speed reduction and fuel consumption and pollutant emissions is also dependent on other factors, such as the drivers' behavior and resulting from traffic jams [38], speed control schemes [39,40], shifting gears on the way through the TCMs [41], etc. For example, Wang et al. [42] indicated the acceleration should be incorporated, instead of mean speed of the vehicle, for estimating emission.

While in extensive urban areas the succession of TCMs leads to a situation wherein vehicles' speeds are relatively under control, a problem arises in the transition from interurban areas to urban areas. This problem is even greater when an interurban road goes through the urban area of a small village without by-passing it [43-46]. When the urban road segment is short, drivers tend not to reduce the speed adequately since the village is not their final destination, and they maintain the high speeds allowed in interurban areas. Hence, the risk for pedestrians is increased (Figure 2). Aiming to reduce the speed of vehicles when crossing these small villages, traffic calming measures are collocated at the entrance of villages to warn drivers that they are entering an urban area, even if it is short, and to force them to speed down.

The first traffic safety analyses on these rural roads crossing short urban areas without a by-pass were conducted in Denmark [47], and in Great Britain [48-50], and later in other countries [51-55]. Therefore, the introduction of traffic calming measures is recommended in many countries [56-63]. Usual solutions at the border between non-urban and urban areas are signs with speed limits, road humps, road markings, rumble devices, road narrowing measures, including chicanes, pinch-points or overrun areas, panels displaying vehicles' speed, radars (which could fine if the speed limit is exceeded), traffic lights turning red in case of exceeding speed limit, raised crosswalk, etc. [45-49,52-56,62-64]. Some studies have examined the effectiveness of these measures at this critical point $[65,66]$. Solowczuk and Kacprzak $[45,46]$ analyzed the factors influencing the effectiveness of on-road chicanes in transition zones to villages subject to 70 and $50 \mathrm{~km} / \mathrm{h}$ speed limits, and proposed one aggregate parameter combining various factors. Factors related to the surrounding landscape and visibility conditions were found to be key factors on speed reduction. Similarly, other authors examined the result of placing traffic lights that turn red if the speed limit is exceeded together with various displays of other measures in different small villages. It was observed that incorporating a panel indicating the vehicles' speed after or before the traffic light turning red in case of exceeding speed limit did not lead to variation in measured speeds $[67,68]$. Additionally, the point with the lowest speed was the traffic lights (since they could get a fine if police was controlling that the red light was controlled). However, after them, drivers speed up at the points where pedestrians could cross the road. Furthermore, it was shown that if the traffic lights turning red were placed with a pedestrian crossing, lower speeds were measured since pedestrians could appear and drivers tend to respect more the speed limit.

The aim of this paper is to evaluate the effectiveness of camera speed radars and panels indicting vehicles' speed at the entrance of small villages in rural roads, observing if drivers reduce their speed when passing next to the TCMs and further in the middle of the small village, where crosswalks are placed to connect the two parts of the small village divided by the road. Two small villages in Poland and two small villages in Spain located along the rural sections of roads were selected for the study. At the entrance of these villages radar speed cameras (which are supposed to fine) or panels indicating vehicles' speed are installed. If low speeds are obtained at the entrance and they are effectively maintained through the entire urban section, a safer and more energy-efficient driving will be developed. 


\section{Materials and Methods}

The two small villages in Poland are Chodorówka Nowa and Suchowola and the two villages in Spain are Arrankudiaga and Arrespalditza/Respaldiza. The display of the traffic calming measures in each village is described individually.

\subsection{Villages in Poland}

Both analyzed villages in Poland are located on the National Road 8 (NR8), included in the international E-network as E67, from Helsinki (Finland) to Prague (Czech Republic). The NR8 road is the main international route in North-Eastern Poland, leading the traffic to the border with Lithuania and, hence, it is characterized with a high percentage of heavy traffic. An annual average daily traffic (AADT) on NR8 reaches almost 10,713 vehicles/day in 2019, implying $8 \%$ increase with regard to 2018. The average AADT for all international roads is almost 16,700 vehicles/day. On the other hand, the percentage of heavy traffic on NR8 (46\%) is distinctly higher when compared to other international roads in Poland (30\%).

The NR8 road crosses the village of Chodorówka Nowa in a length of approximately $790 \mathrm{~m}$. In the middle part of the urban segment, there is a road intersection with a pedestrian crossing enabling to cross the NR8 road. At approximately $150 \mathrm{~m}$ before the crosswalk there is a radar speed camera. The existing elements in the urban segment, from the North to the South are as follows (Figure 3a):

- A sign with the village name (1);

- Radar speed camera, fining vehicles going southbound (2);

- Pedestrian crossing (3).
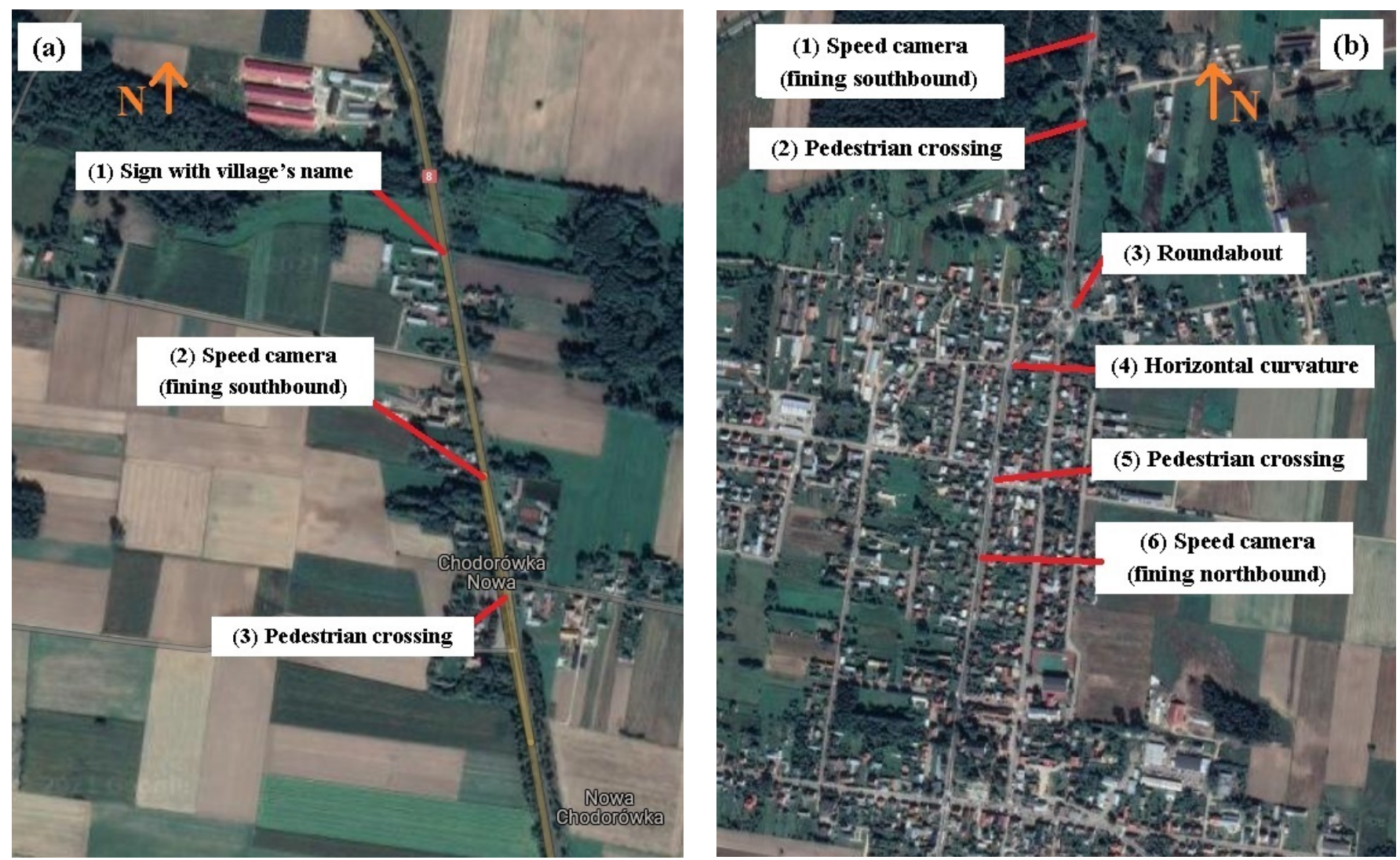

Figure 3. Locations of the traffic calming measures and other elements in (a) Chodorówka Nowa; (b) Suchowola.

Vehicles speeds were measured in both directions at the three points (the entrance/exit of the village, the speed camera, and the pedestrian crossing). Points are referred to as S1, S2, and S3, when measuring southbound, and N1, N2, and N3 northbound. 
The second village investigated in Poland is Suchowola. The length of the urban segment is approximately $3500 \mathrm{~m}$ and there are speed cameras situated along the NR8 road and spaced at different distances. The traffic calming measures and important points in the urban segment (Figure 3b), from north to south are as follows:

- $\quad$ Speed camera (fining vehicles southbound) (1), $30 \mathrm{~m}$ south from the sign with the village name;

- $\quad$ Pedestrian crossing (2), $60 \mathrm{~m}$ away from the speed camera in point 1;

- $\quad$ Roundabout (3);

- Horizontal curvature (4);

- Pedestrian crossing (5), $210 \mathrm{~m}$ south from the horizontal curvature, which creates a physical deflection influencing vehicles' speed;

- $\quad$ Speed camera faced northbound (6), $120 \mathrm{~m}$ from the crosswalk in point 5.

Speed measurements were conducted in point 1 (speed camera), point 2 (pedestrian crossing), and point 5 (pedestrian crossing). They are called N1 or S1, N2 or S2, and N5 and S5, depending on the direction of the traffic (northbound or southbound), respectively.

\subsection{Villages in Spain}

The first village in Spain is Arrankudiaga, located in the province of Biscay. It is crossed by the road BI-625, which belongs to the basic network (orange network), the second level between the road network levels in the province [69]. The Regional Government of Biscay manages all the roads in the territory, even the freeways or national roads [70] so it means an important road. It has an AADT of 12,855 vehicles/day, with $8 \%$ of heavy vehicles [71]. The urban length is approximately $900 \mathrm{~m}$ and the sequence of traffic calming measures and elements in the urban area are (Figure 4), from north to south are:

- Signs and panels indicating that the speed limit is $50 \mathrm{~km} / \mathrm{h}$ and the presence of a speed camera (1) and (2);

- $\quad$ Traffic lights with a pedestrian crossing and a pushbutton (3);

- Radar speed camera faced to control vehicles northbound (4);

- Traffic lights with pedestrian crossing and a pushbutton (5);

- Signs and panels indicating that the speed limit is $50 \mathrm{~km} / \mathrm{h}$ and the presence of a speed camera (6) and (7).

Measurements were carried out at the pedestrian crossings with traffic lights and pushbuttons (3) and (5) and at the radar speed camera (4) northbound. Once again, points are referred to as N3, N4, and N5 or S3, and S5, depending on the controlled direction, northbound and southbound, respectively.

The second village in Spain is Arrespalditza/Respaldiza, in the province of Álava. The road A-624 crosses the village in a length of $415 \mathrm{~m}$. The road belongs to the basic road network (the orange network), which is also the second level of the road networks in the province. The Regional Government of Alava also manages all the roads in the territory, even the freeways or national roads [70]. The road A-624 has an AADT of 3505 vehicles per day near Arrespalditza/Respaldiza, with $4 \%$ of heavy vehicles [72]. The traffic calming measures and the main elements on the urban segment (Figure 5) from north to south are as follows:

- A panel indicating the presence of traffic light (1);

- A panel indicating the speed of each vehicle (with a speed limit of $50 \mathrm{~km} / \mathrm{h}$ ) for vehicles going southbound (2);

- $\quad$ Traffic lights with a pedestrian cross walk and a pushbutton (3);

- $\quad$ Pedestrian crossing (4);

- $\quad$ Traffic lights warning about the presence of traffic lights (5);

- A panel indicating the speed of each vehicle (with a speed limit of $50 \mathrm{~km} / \mathrm{h}$ ) for vehicles going northbound (6).

Measures were conducted at the pedestrian crossing (4), and $25 \mathrm{~m}$ after the crosswalk with traffic lights with a pushing button at the point (3), southbound. This last point aimed 
to measure the speed not just at the TCM but at a certain distance. Additionally, the speed was measured in the places of both panels indicating the vehicles' speed (2) and (6). Points are referred to as N3, N4, and N6, or S2, S3, and S4, according to the direction of the vehicles, northbound or southbound, respectively.

Speed measures were obtained by fixed radars or by radar guns. A minimum of 200 vehicles were measured at each place, in each direction.

For the four villages, the following speed parameter values are provided: the maximum speed $\left(V_{\max }\right)$, the average speed $\left(V_{m}\right)$, and the 85 th percentile of the speed distribution $\left(\mathrm{V}_{85}\right)$, which is the speed at or below which 85 percent of the motorists drive on a given road. Additionally, the total number of vehicles controlled, the number of vehicles exceeding the speed limit $(50 \mathrm{~km} / \mathrm{h})$ and the percentage of vehicles that exceeded the speed limit are also presented.

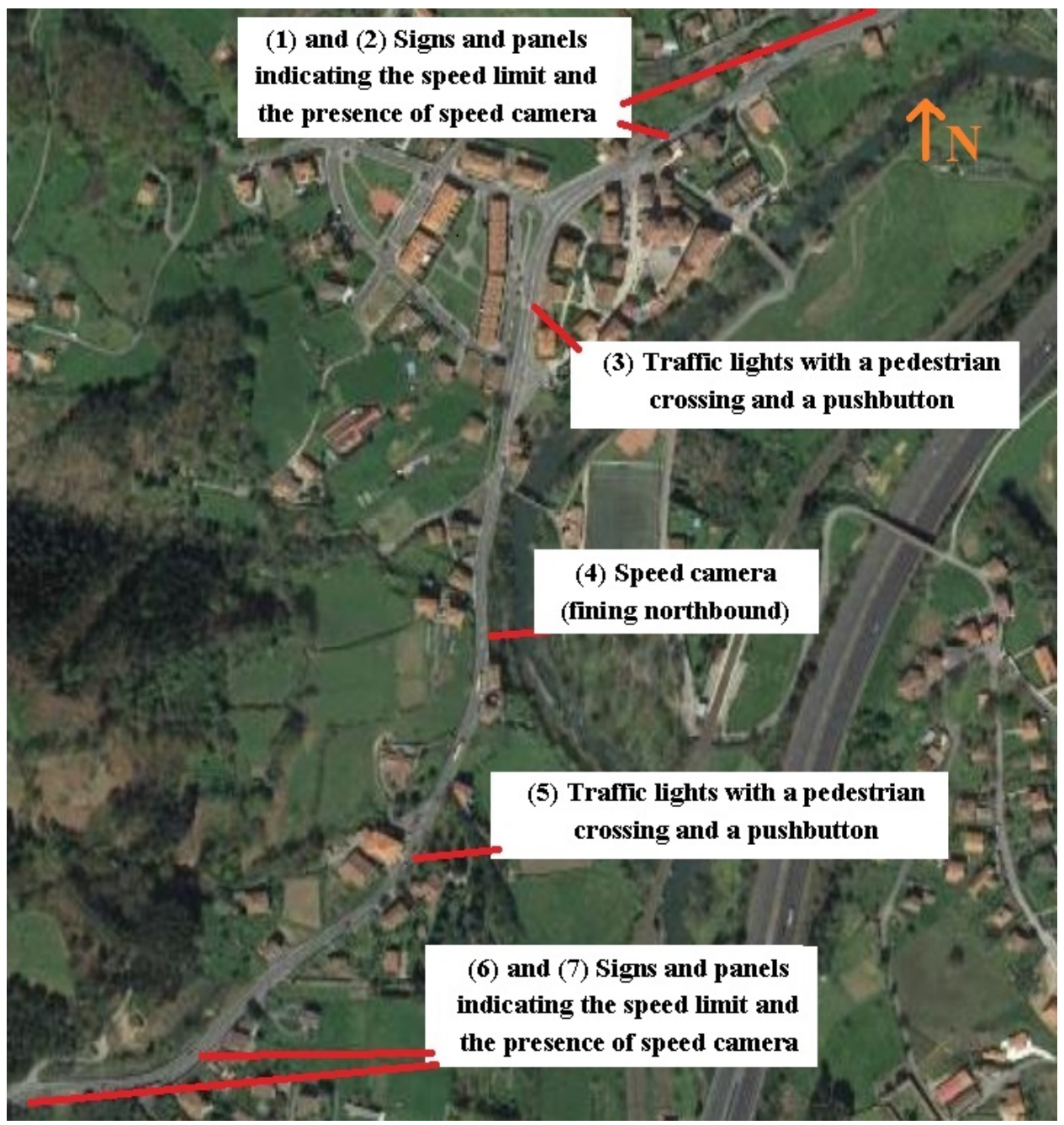

Figure 4. Locations of the traffic calming measures and other elements in Arrankudiaga (Spain). 


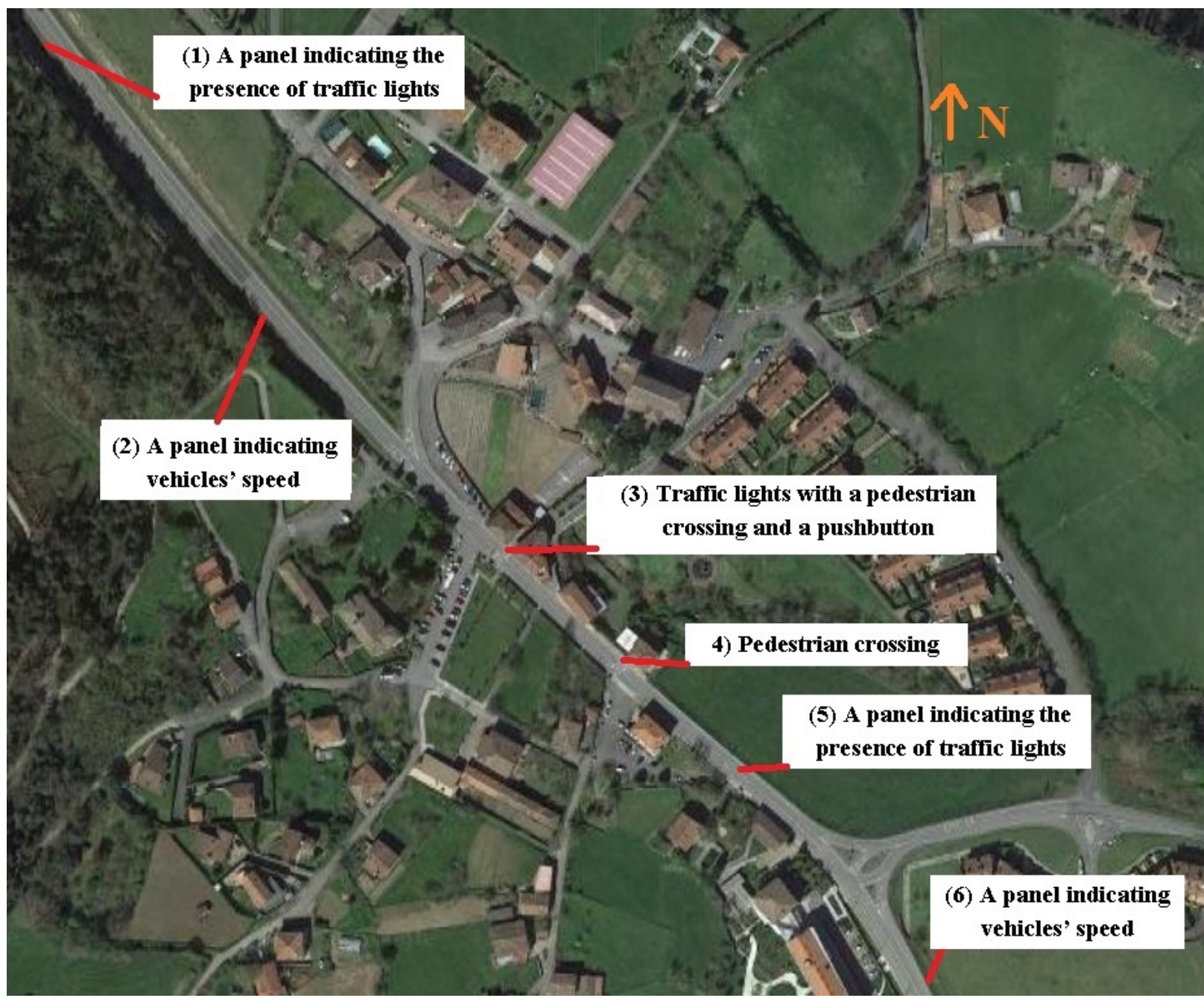

Figure 5. Locations of the traffic calming measures and other elements in Arrespalditza/Respaldiza (Spain).

\section{Results and Discussion}

More than 28,000 vehicles were controlled in all the locations. Results are presented individually.

\subsection{Results in Chodorówka Nowa (Poland)}

Table 2 presents the results for Chodorówka Nowa.

Table 2. Values of selected variables at control points in Chodorówka Nowa.

\begin{tabular}{ccccccc}
\hline Points & $\begin{array}{c}\text { S1 } \\
\text { Entrance }\end{array}$ & $\begin{array}{c}\text { S2 } \\
\text { Radar }\end{array}$ & $\begin{array}{c}\text { S3 } \\
\text { Crosswalk }\end{array}$ & $\begin{array}{c}\text { N3 } \\
\text { Crosswalk }\end{array}$ & $\begin{array}{c}\text { N2 } \\
\text { Radar }\end{array}$ & $\begin{array}{c}\text { N1 } \\
\text { Exit }\end{array}$ \\
\hline $\mathrm{V}_{\mathrm{m}}(\mathrm{km} / \mathrm{h})$ & 64.5 & 48.6 & 54.4 & 51.7 & 49.5 & 64.6 \\
$\mathrm{~V}_{85}(\mathrm{~km} / \mathrm{h})$ & 72 & 54 & 60 & 58 & 54 & 76 \\
$\mathrm{~V}_{\max }(\mathrm{km} / \mathrm{h})$ & 96 & 64 & 76 & 84 & 65 & 99 \\
Total number & 200 & 200 & 200 & 200 & 200 & 200 \\
Vehicles with $\mathrm{v}>50 \mathrm{~km} / \mathrm{h}($ number $)$ & 196 & 69 & 166 & 111 & 101 & 50.5 \\
Vehicles with $\mathrm{v}>50 \mathrm{~km} / \mathrm{h}(\%)$ & 98 & 34.5 & 83 & 55.5 & 89 \\
\hline
\end{tabular}

As seen, southbound high speeds are registered at the entrance of the village, which is common, since drivers maintain the speed of an interurban road even if they are entering the area of $50 \mathrm{~km} / \mathrm{h}$ speed limit. Then, in the next point, due to the presence of the radar speed camera, they speed down, reaching the lowest speeds in this controlled village. 
However, $34.5 \%$ of the vehicles still exceeded the speed limit. In the final point, at the pedestrian crosswalk, speeds have increased so distinctly that the average went up over the limit. $83 \%$ of drivers violate the speed limit, even though they are still in an urban area at a place of potentially higher risk (pedestrian crossing) (Figure 6).

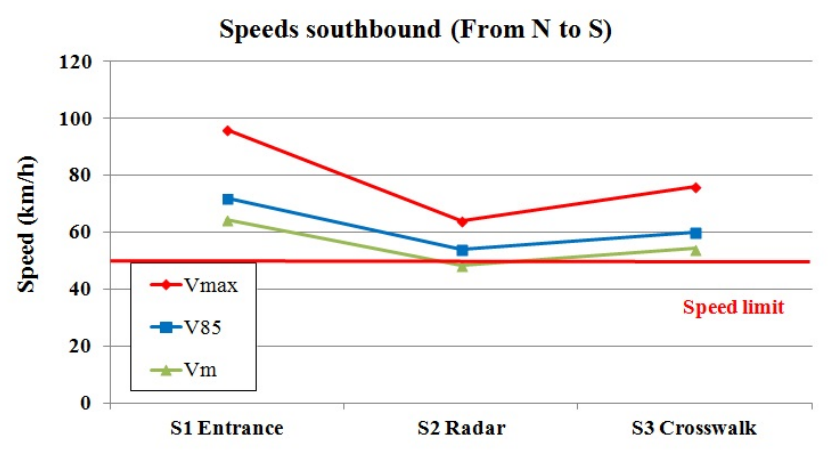

(a)

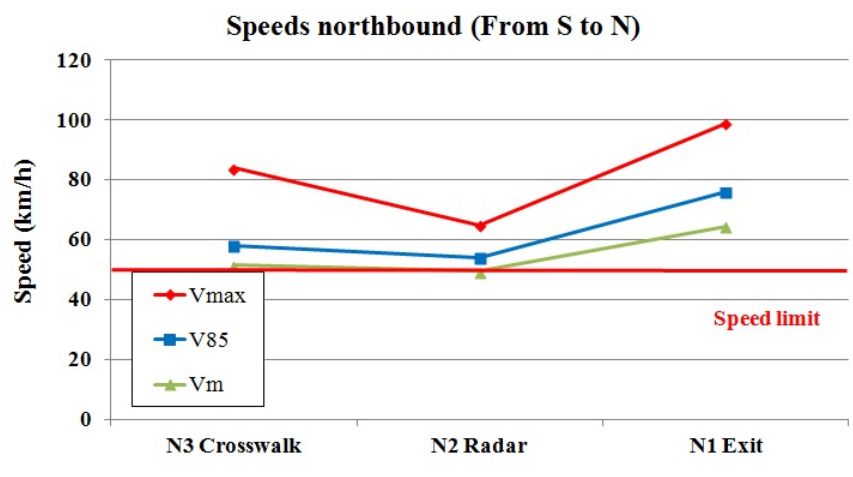

(b)

Figure 6. Speed at each controlled point in Chodorówka Nowa (Poland): (a) southbound, (b) northbound.

In the opposite direction, from south to north, lower speed values and number of violating drivers are registered. Drivers approaching the crosswalk seem to react correctly and reduce travel speed in advance. The visual effect of this is that only $55.5 \%$ exceed the speed limit comparing with $83 \%$ of speeding drivers in the opposite direction. Nonetheless, this value of exceeding drivers is still highly alarming. At the radar point, the average speed and 85th percentile are on a similar level to the values recorded in southbound direction. Despite the fact that the speed limit in force in urban areas is $50 \mathrm{~km} / \mathrm{h}$, it is common in Poland that speed cameras give drivers $10 \mathrm{~km} / \mathrm{h}$ tolerance over the speed limit. This is partly due to technological limitations of the speed cameras and partly due to the limitations of the system and authority responsible for issuing the tickets. Unfavorably, this fact is generally known by drivers and they take risk of speeding over the limit, which is reflected in a high number of registered drivers' violations. Finally, at the exit of the village, which is approximately $400 \mathrm{~m}$ away from the speed radar, similar values to the entrance are registered.

Hence, it can be said that the radar makes drivers speed down, especially in the direction they could be fined, albeit not excessively as more than a third do not respect it, and at the crosswalk (the point more important to reduce the speed in terms of vulnerable road users' safety), the effect of the radar is not achieved. As soon as drivers pass the control point (speed radar) they accelerate regardless of the speed limit.

\subsection{Results in Suchowola (Poland)}

Results for Suchowola are listed in Table 3 and graphically presented in Figure 7.

Table 3. Values of selected variables at control points in Suchowola (Poland).

\begin{tabular}{ccccccc}
\hline Points & $\begin{array}{c}\text { S1 } \\
\text { Radar }\end{array}$ & $\begin{array}{c}\text { S2 } \\
\text { Crosswalk }\end{array}$ & $\begin{array}{c}\text { S5 } \\
\text { Crosswalk }\end{array}$ & $\begin{array}{c}\text { N5 } \\
\text { Crosswalk }\end{array}$ & $\begin{array}{c}\text { N2 } \\
\text { Crosswalk }\end{array}$ & $\begin{array}{c}\text { N1 } \\
\text { Radar }\end{array}$ \\
\hline $\mathrm{V}_{\mathrm{m}}(\mathrm{km} / \mathrm{h})$ & 50.3 & 53.2 & 47.4 & 47.1 & 52.1 & 55.3 \\
$\mathrm{~V}_{85}(\mathrm{~km} / \mathrm{h})$ & 54 & 59 & 53 & 54 & 58 & 63 \\
$\mathrm{~V}_{\max }(\mathrm{km} / \mathrm{h})$ & 72 & 75 & 65 & 63 & 81 & 81 \\
Total number & 200 & 200 & 200 & 200 & 200 & 200 \\
Vehicles with $\mathrm{v}>50 \mathrm{~km} / \mathrm{h}($ number $)$ & 102 & 128 & 58 & 78 & 125 & 143 \\
Vehicles with $\mathrm{v}>50 \mathrm{~km} / \mathrm{h}(\%)$ & 51 & 64 & 29 & 39 & 62.5 & 71.5 \\
\hline
\end{tabular}




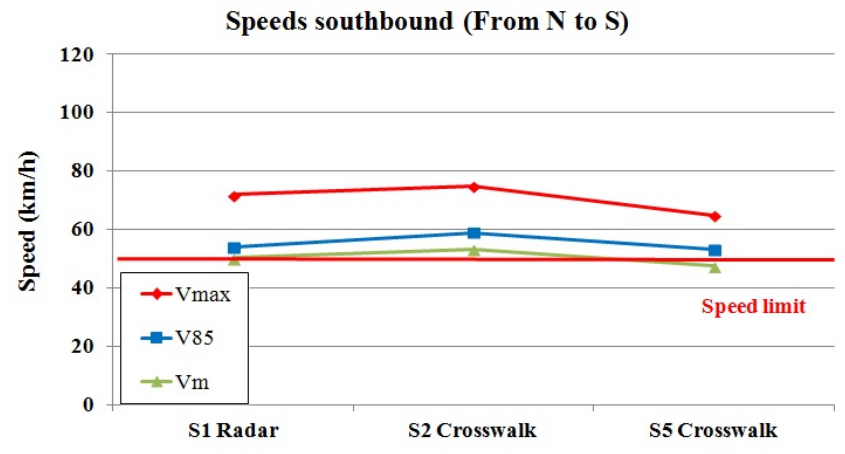

(a)

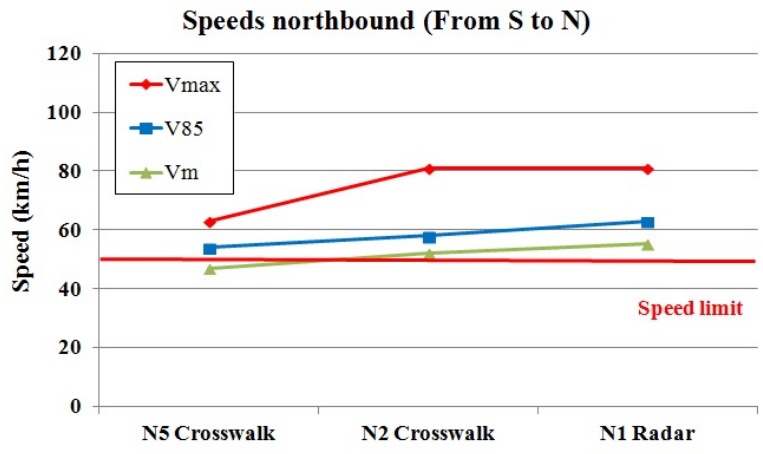

(b)

Figure 7. Speed at each controlled point in Suchowola (Poland): (a) southbound, (b) northbound.

As shown, in southbound, the first controlled point, S1, where a radar speed camera is installed, vehicles' speed decrease, and drivers adapt their values to the urban area. Although the average value is slightly over the speed limit, and hence, $51 \%$ of the vehicles do not respect the limit, but the $\mathrm{V}_{85}$ is very near to it, $54 \mathrm{~km} / \mathrm{h}$. It means, that approximately the majority of the vehicles adapted their speed due to the presence of the radar, although not totally conveniently. In the following control point, S2, a crosswalk, drivers speeded up and $64 \%$ exceeded the limit, meaning that the effect of the radar is very short as the pedestrian crossing is only $75 \mathrm{~m}$ away from the speed radar. Finally, at point S5, a crosswalk in the village located after a roundabout and a horizontal deflection the best values of the speed were obtained; only $29 \%$ of drivers travel over the speed limit and $\mathrm{V}_{85}$ is only $53 \mathrm{~km} / \mathrm{h}$. It clearly shows that in long urban areas speeds tend to be adapted to this area, getting better results since some vehicles turn in the intersections of the villages or new vehicles are incorporated to the main traffic flow. In the opposite direction, from South to North, very the same $V_{m}$ and $V_{85}$ values, in relation to S5, are registered in N5, due to the presence of a radar speed camera located $120 \mathrm{~m}$ before. In Suchowola, the speed values are almost the same in the same check points regardless the direction. In point N2, located at the end of the village, low-density housing in road vicinity makes drivers feel that the village has finished and even the presence of a crosswalk does not make speed down. The average speed is over the limit with $62.5 \%$ of drivers exceeding it. Finally, in $\mathrm{N} 1$, as the radar cannot fine vehicles northbound, higher values than in N2 are registered since drivers being forced to drive with a low speed along the whole village $(3500 \mathrm{~m})$ feel frustrated and trying to regain lost time accelerate earlier before the administrative border of the village is reached without worrying about the presence of the radar.

\subsection{Results in Arrankudiaga (Spain)}

Analyzed variables from the data registered in Arrankudiaga are shown in Table 4 and Figure 8.

Table 4. Values of selected variables at control points in Arrankudiaga (Spain).

\begin{tabular}{|c|c|c|c|c|c|}
\hline Points & $\begin{array}{c}\text { N5 } \\
\text { Crosswalk }\end{array}$ & $\begin{array}{c}\text { N4 } \\
\text { Radar }\end{array}$ & $\begin{array}{c}\text { N3 } \\
\text { Crosswalk }\end{array}$ & $\begin{array}{c}\text { S3 } \\
\text { Crosswalk }\end{array}$ & $\begin{array}{c}\text { S5 } \\
\text { Crosswalk }\end{array}$ \\
\hline $\mathrm{V}_{\mathrm{m}}(\mathrm{km} / \mathrm{h})$ & 50.9 & 45.9 & 46.0 & 49.7 & 54.4 \\
\hline $\mathrm{V}_{85}(\mathrm{~km} / \mathrm{h})$ & 59 & 51 & 54 & 59 & 63 \\
\hline $\mathrm{V}_{\max }(\mathrm{km} / \mathrm{h})$ & 124 & 64 & 77 & 88 & 108 \\
\hline Total number & 4047 & 794 & 4685 & 4615 & 4551 \\
\hline Vehicles with $\mathrm{v}>50 \mathrm{~km} / \mathrm{h}$ (number) & 2187 & 141 & 1485 & 2332 & 3290 \\
\hline Vehicles with v > $50 \mathrm{~km} / \mathrm{h}(\%)$ & 54.0 & 17.8 & 31.7 & 50.5 & 72.3 \\
\hline
\end{tabular}




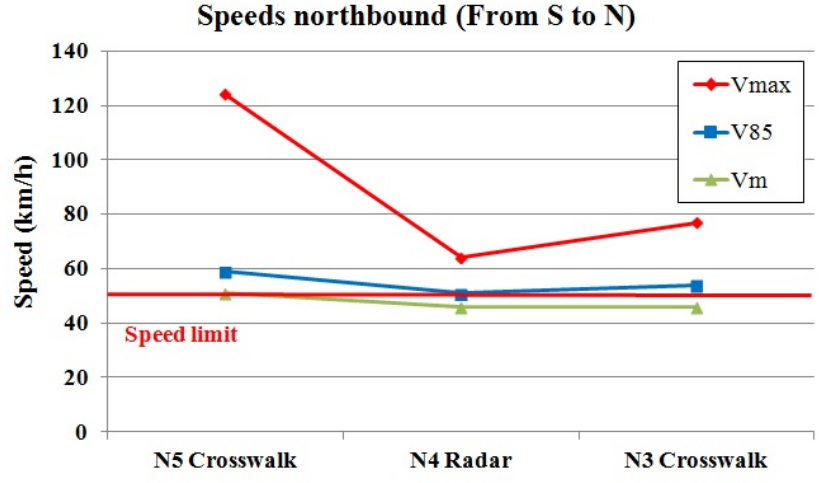

(a)

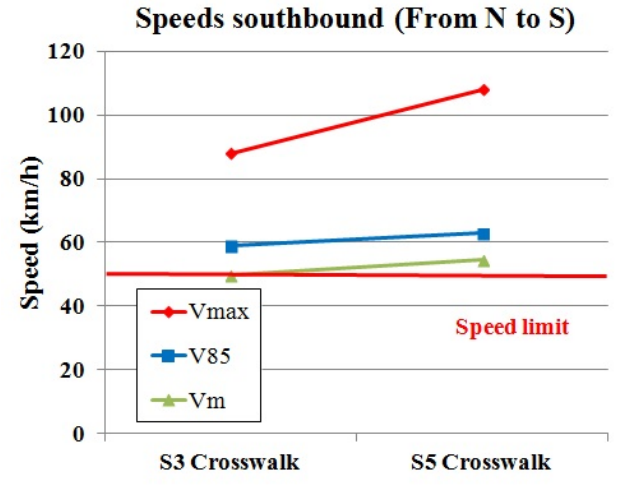

(b)

Figure 8. Speed at each controlled point in Arrankudiaga (Spain): (a) southbound, (b) northbound.

Observing the data, it can be deduced that the presence of a radar speed camera has a real influence on the vehicles' speed when comparing the values of the two directions. Northbound, the first crosswalk serves as a way to indicate that drivers are in an urban area. At the radar, in the direction to the north, the lowest speed values are registered, with the $\mathrm{V}_{85}$ near the speed limit $(50 \mathrm{~km} / \mathrm{h})$, and only $17.8 \%$ of drivers exceed it. Later, at the following crosswalk (with traffic lights and a pushbutton), better speed values than in the previous one are obtained, meaning that the radar has an effect on drivers' behavior, making that only $31.7 \%$ of them drive with the speed over $50 \mathrm{~km} / \mathrm{h}$ (Figure 8 ). Nevertheless, southbound results are not so satisfactory. Although there is a high AADT in the road, the traffic is local (no international traffic uses this road) and the habitual drivers know that the radar speed camera can only fine northbound. Hence, southbound drivers do not feel any possibility of infraction and higher values are recorded in both crosswalks, especially in the second one (S5), which is after the radar and near the exit of the village, with almost three quarts of the drivers exceeding the limit.

If compared with Polish data, fewer drivers exceeded the speed limit at the point of the radar. Spanish drivers also know that there is a tolerance between the speed limit and the real speed to get a fine, but it is observed that fewer drivers take the risk of exceeding the limit. The tolerance in radar speed camera measurement is a fact known in the entire European Union, but other factors can be attributed to the variable degrees of vehicles violating it such as a culture of driving fast, the observed probability of appearing a pedestrian according to the number of inhabitants in the village, etc.

\subsection{Results in Arrespalditza/Respaldiza (Spain)}

Analyzed variables from the data registered in Arrespalditza/Respalditza are displayed in Table 5.

Table 5. Values of selected variables at control points in Arrespalditza/Respaldiza (Spain).

\begin{tabular}{|c|c|c|c|c|c|c|}
\hline Points & $\begin{array}{c}\text { S2 } \\
\text { Panel }\end{array}$ & $\begin{array}{c}\text { S3 } \\
\text { Crosswalk } \\
\text { + Traffic } \\
\text { Lights }\end{array}$ & $\begin{array}{c}\text { S4 } \\
\text { Crosswalk }\end{array}$ & $\begin{array}{c}\text { N6 } \\
\text { Panel }\end{array}$ & $\begin{array}{c}\mathrm{N} 4 \\
\text { Crosswalk }\end{array}$ & $\begin{array}{c}\text { N3 } \\
\text { Crosswalk } \\
\text { + Traffic } \\
\text { Lights }\end{array}$ \\
\hline $\mathrm{V}_{\mathrm{m}}(\mathrm{km} / \mathrm{h})$ & 68.6 & 48.5 & 43 & 63.9 & 46.7 & 52.1 \\
\hline $\mathrm{V}_{85}(\mathrm{~km} / \mathrm{h})$ & 77 & 61 & 51 & 79 & 56 & 65 \\
\hline $\mathrm{V}_{\max }(\mathrm{km} / \mathrm{h})$ & 112 & 112 & 92 & 117 & 91 & 113 \\
\hline Total number & 200 & 1729 & 1483 & 211 & 1723 & 1951 \\
\hline Vehicles with $\mathrm{v}>50 \mathrm{~km} / \mathrm{h}$ (number) & 196 & 690 & 255 & 168 & 539 & 1083 \\
\hline Vehicles with $\mathrm{v}>50 \mathrm{~km} / \mathrm{h}(\%)$ & 98 & 39.9 & 17.2 & 79.6 & 31.3 & 55.5 \\
\hline
\end{tabular}


The first thing that can be observed from Table 5 is that the panels indicating the speed are not effective. They alert one about the presence of an urban area but they do not cause a speed reduction since drivers know that they cannot be fined at that point. They regard them as warning signals, but not as a punishing measure. Therefore, the majority of drivers do not respect the speed limit at these points $(98 \%$ southbound and 79.6 northbound (Figure 9)). Later, at the pedestrian crossing, speed limit is more respected by motorists, with more than the half of vehicles respecting the speed limit, except for N3. The most appropriate drivers' behavior in terms of travel speed were obtained in point (3), at the location of the cross walks, where only $17.2 \%$ and $31.3 \%$ of the drivers do not respect the speed limit. Higher values were registered at $25 \mathrm{~m}$ from the traffic lights at the crosswalk with the pushing button, where the average speed slightly exceeds the limit of the urban area. However, $V_{85}$ value, which is the usual variable in traffic engineering, is much above the limit.

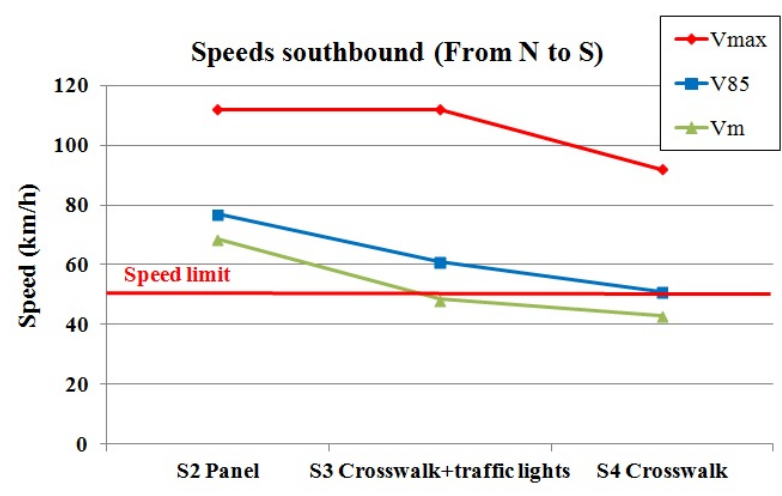

(a)

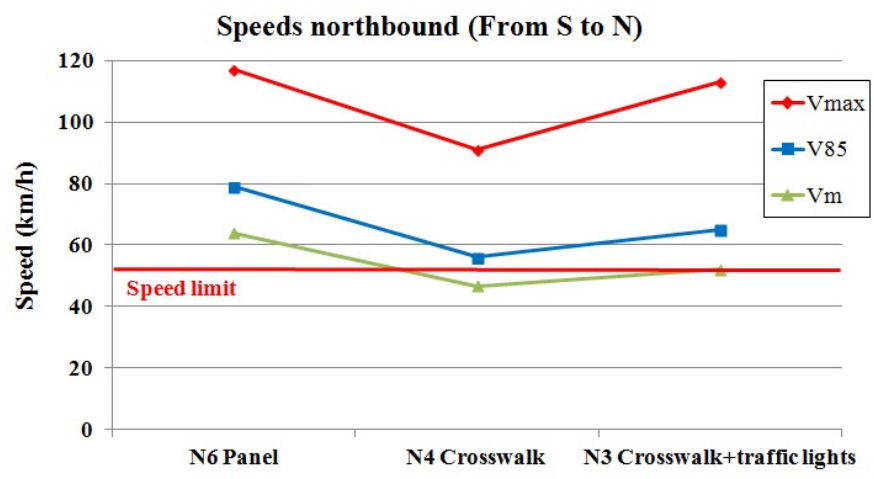

(b)

Figure 9. Speed at each controlled point in Arrespalditza/Respaldiza (Spain): (a) southbound, (b) northbound.

\subsection{Discussion}

Very detailed equations cannot be extracted for some speed measurement in various villages since speed does not only depend on the existing traffic calming measures. Speed in short urban areas also depends on many other variables, such as, the exact location of the TCMs, the type of drivers (habitual or not), the geometry of the segment, the length of the short urban area, the usual speeds after and before the urban area, the building density of the village, the number of inhabitants, etc. Nevertheless, some general ideas are possible to be deduced from this study.

Firstly, the presence of radar speed cameras force drivers to speed down, mostly due to the risk of being fined if speed limit is exceeded. When comparing values in both directions, and the speed camera is only able to fine in one direction, better results (i.e., lower speeds) can be obtained in the direction that the radar can fine, especially if the speed camera is located in the outskirts of the built-up area. This can be clearly observed in Suchowola when values at S1 (fining) and N1 (non-fining) differ distinctly (10\% difference). If the speed camera is located in a middle of a built-up area and drivers' speed is additionally affected by other factors (buildings around the road, road curvature or roundabout presence) the speeds in a certain distance are very similar regardless of the direction of the movement (S5 and N5). Another common finding for both villages in Poland is the short range of speed radar exposure. Drivers, being forced to slow down while passing the radar, start to accelerate, and their speed rises shortly after. This phenomenon is in accordance with the findings of previous researches [73,74]. At the place of the pedestrian crossings speed values depend on the direction of the movement if the speed camera is located within a reasonable distance; drivers approaching a speed camera reduce their speed more than those driving away. This is visible when comparing values in Chodorówka Nowa at the S3 (fining direction) with N3 (non-fining) directions. Furthermore, this effect of the presence 
of a radar speed camera and its orientation can be observed also in other elements. This is the case of Arrankudiaga, where northbound speeds were lower at the pedestrian crossing walks than southbound (N5 vs. S5 and N3 vs. S3). Hence, the positive effect of the radar speed camera on speed in that direction must be noted.

Secondly, placing traffic calming measures far from the real start of the village has low effect on vehicles' speed. This is perfectly observable in Arrespalditza/Respaldiza at points S2 and N6, where the panels indicating the speed, which include a speed limit of $50 \mathrm{~km} / \mathrm{h}$, are not effective, as drivers feel that the start of the village is not at that point and, hence, do not respect it. When compared these two panels, lower values are recorded in N6 than at S2, since N6 is placed nearer the entrance of the urban area. The effect on the closeness of the panel indicating the speed to the village has been previously investigated [68]. In that research it was shown that if the panel was further from the start of the village, higher speeds were registered. Additionally, something similar happens in Chodorówka Nowa, in N1. Although there is not a TCM at this point (it is just the panel with the village's name), and the speed limit of $50 \mathrm{~km} / \mathrm{h}$ theoretically starts there, as drivers still do not really feel the presence of an urban area they regard the panel with the name as an informative one instead of a signal of a lower speed limit area. This additionally confirms the low effectiveness of administrative speed limitations (vertical signs) as a measure of speed management [75]. Consequently, with the aim of obtaining better results, TCMs at the borders between urban and non-urban areas should be placed as near as possible to the real urban area.

Thirdly, the effect of a radar speed camera is higher in the place of occurrence than at a pedestrian crossing located in some distance after the speed camera. The effect is highly disappointing comparing values of $\mathrm{V}_{\mathrm{m}}$ and $\mathrm{V}_{85}$ between speed radar and the nearest pedestrian crossings. Drivers respect more a possible fine than a crosswalk, especially if no pedestrians are visible. Some points to observe this trend are S1 and S2 in Suchowola, and N4 and N3 in Arrankudiaga. In fact, radar speed camera must be regarded as a punctual TCM, which is generally respected by motorist (due to the risk of fine), but at that point, without achieving a real decrease of the speed in the subsequent segment $[25,66]$. In the measuring points after the radar speed cameras higher values are registered, confirming the idea of a punctual TCM. Furthermore, normally, lower speed values are measured some meters before the radar speed camera than some meters after it [66].

Lastly, if the urban segment is longer, lower values are obtained. The best example is the point S5 in Suchowola, where low speeds were measured, $970 \mathrm{~m}$ in urban area after S1 point, a roundabout and a horizontal deflection. The values in S5 are lower even than the ones in S1, where a radar speed camera is situated. The successive presence of measures affecting the travel speed (roundabouts, horizontal curvatures) distinctly influence on the speed. However, on the contrary, when drivers feel that the urban area is finishing, they speed up again, even if the real urban area is not finished. This can be regarded in Suchowola in points N2 and N1. The urban area is not finished "per se", but as there are not so many buildings in that area, motorists start adapting their speed to the new area, an interurban area.

\section{Conclusions}

With the aim of analyzing various traffic calming measures on rural roads that pass through short urban areas, four small villages without a by-pass road were selected and analyzed (two in Poland and two in Spain). Amongst analyzed traffic calming measures there were radar speed cameras and panels indicating vehicles' speed. Speed values were recorded at the place of the traffic calming measures and at the pedestrian crossings, which are the most important and sensitive places, as vulnerable road users will use them to go from one to the other side of the village.

Although the real effect of each TCM does not depend uniquely on the TCM itself, some general ideas can be obtained from the analysis of the results in these four villages. 
If a radar speed camera can only fine in one direction, drivers on that direction would respect it more than in the other direction. Additionally, a positive effect was registered not only at the place of the radar speed camera. It also extended to some distance in front of and behind the camera. Values obtained at the crosswalks indicated that the presence of the speed camera in that direction directly influenced the motorists' speed behavior but that the impact diminishes with distance. It must be underlined that the effect of the speed camera does not last long, and drivers speed up after having crossed that critical point. Furthermore, it should be emphasized that the general effect of radar speed cameras is also partially mitigated by a tolerance for speeding drivers in the camera's settings. Continuous technological development should enable one to replace existing devices with new, more accurate ones, and the radar camera's speed limit thresholds should be narrowed and closer to the real limits.

Moreover, it was seen that if the TCMs are located far from the real start of the urban area, even if they impose a speed limit, they are not respected until drivers feel that the real urban area and the possibility of pedestrians appearing really started. Therefore, it is recommended to place TCMs near the real start of the built-up area.

Finally, longer urban areas make decrease the speed more, as the continuous succession of intersections have a real effect on speed. On the contrary, when motorists feel that the urban area is finished, they start speeding up to get usual speed of non-urban roads.

Author Contributions: All the authors have contributed to this work similarly. All authors have read and agreed to the published version of the manuscript.

Funding: This research was funded by GIRDER Ingenieros, S.L.P., grant number 2019.0478, by "Erasmus + programme-Call 2016-KA1-Mobility of Staff in higher education-Staff mobility for teaching and training activities", and by Project No WZ/WB-IIL/1/2020 and it was financially supported by Ministry of Science and Higher Education, Poland.

Institutional Review Board Statement: Not applicable.

Informed Consent Statement: Not applicable.

Data Availability Statement: The data presented in this study are available in the article.

Conflicts of Interest: The authors declare no conflict of interest.

\section{References}

1. Llopis-Castelló, D.; Findley, D.J. Influence of calibration factors on crash prediction on rural two-lane two-way roadway segments. J. Transp. Eng. A Syst. 2019, 145, 040190241-040190249. [CrossRef]

2. Shad, S.A.R.; Ahmad, N. Road infrastructure analysis with reference to traffic stream characteristics and accidents: An application of benchmarking based safety analysis and sustainable decision-making. Appl. Sci. 2019, 9, 2320. [CrossRef]

3. European Commission. Annual Statistical Report on Road Safety in the EU 2020; European Road Safety Observatory: Brussels, Belgium, 2021.

4. European Commission. Facts and Figures_Pedestrian; European Road Safety Observatory: Brussels, Belgium, 2020.

5. European Commission. Road Safety Thematic Report_Pedestrians; European Road Safety Observatory: Brussels, Belgium, 2021.

6. Hall, J.W.; Smith, K.L.; Titus-Glover, L.; Wambold, J.C.; Yager, T.J.; Rado, Z. Guide for Pavement Friction; Contractor's Final Report for NCHRP-Project 01-43; Transportation Research Board: Washington, DC, USA, 2009.

7. Chen, Y.; Li, Y.; King, M.; Shi, Q.; Wang, C.; Li, P. Identification methods of key contributing factors in crashes with high number of fatalities and injuries in China. Traffic Inj. Prev. 2016, 17, 878-883. [CrossRef]

8. Pérez-Acebo, H.; Gonzalo-Orden, H.; Rojí, E. Skid resistance prediction for new two-lane roads. Proc. Inst. Civ. Eng. Transp. 2019, 172, 264-273. [CrossRef]

9. Treat, J.R.; Tumbas, N.S.; McDonald, S.T.; Shinar, D.; Hume, R.D. Tri-Level Study of the Causes of Traffic Accidents: Executive Summary; Technical Report No. DOT HS-805 099; National Technical Information Services: Bloomington, IN, USA, 1979.

10. European Commission. Road Safety Thematic Report_Speeding; European Road Safety Observatory: Brussels, Belgium, 2021.

11. Rosén, E.; Sander, U. Pedestrian fatality risk as a function of car impact speed. Accid. Anal. Prev. 2009, 41, 536-542. [CrossRef] [PubMed]

12. Hesjesvol, I.; Hoye, A. Pedestrian Crossing Options. Handbook of Road Safety Measures. Available online: https://www. tshandbok.no/del-2/3-trafikkregulering/doc663/ (accessed on 15 February 2021).

13. Yue, L.; Abdel-Aty, M.; Wu, Y.; Zheng, O.; Yuan, J. In-depth approach for identifying crash causation patterns and its implications for pedestrian crash prevention. J. Saf. Res. 2020, 73, 119-132. [CrossRef] 
14. Populer, M.; Chalanton, I.M. Focant, N. Ongevallen met Voetgangers op of in de Buurt van Lichtengeregelde Voetgangersoversteekplaatsen; VIAS Institute: Brussels, Belgium, 2018.

15. Dupriez, B.; Houdmont, A. Gedetailleerde Analyse van Ongevallen in het Brussels Hoofdstedelijk Gewest (2000-2005); D/2009/0779/87; Brussels Mobility: Brussels, Belgium, 2009.

16. International Transport Forum-OECD. Speed and Crash Risk. Research Report; International Traffic Safety Data and Analyses Group: Paris, France, 2018.

17. The Polish General Police Headquarters. Road Accidents in Poland in 2019; Traffic Department: Warsaw, Poland, 2020.

18. Paszkowski, J.; Hermann, M.; Richter, M.; Szarata, A. Modelling the effects of traffic-calming introduction to volume-delay functions and traffic assignment. Energies 2021, 14, 3726. [CrossRef]

19. Ziolkowski, R.; Dziejma, Z. Investigations of the dynamic travel time information impact on drivers' route choice in an urban area-A case study based on the city of Bialystok. Energies 2021, 14, 1645. [CrossRef]

20. Solowczuk, A. Effect of traffic calming in a downtown district of Szczecin, Poland. Energies 2021, 14, 5838. [CrossRef]

21. Loprencipe, G.; Moretti, L.; Pantuso, A.; Banfi, E. Raised pedestrian crossing: Analysis of their characteristics on a road network and geometric sizing proposal. Appl. Sci. 2019, 9, 2844. [CrossRef]

22. Lockwood, I.M. ITE Traffic Calming Definitios. ITE J. 1997, 67, 22-24.

23. Ewing, R.H. Traffic Calming: State of the Practice (FHWA-RD-99-135); Institute of Transportation Engineers (ITE) \& Federal Highway Administration (FHWA): Washington, DC, USA, 1999.

24. Harvey, T. A Review of Current Traffic Calming Techniques; University of Leeds: Leeds, UK, 2013.

25. Gonzalo-Orden, H.; Rojo, M.; Pérez-Acebo, H.; Linares, A. Traffic calming measures and their effect on the variation of speed. Transp. Res. Proc. 2016, 18, 349-356. [CrossRef]

26. Kveladze, I.; Agerholm, N. Visual analysis of speed bumps using floating car dataset. J. Locat. Based Serv. 2018, 12, 119-139. [CrossRef]

27. Ziolkowski, R. Speed management efficacy on national road-Early experiences of sectional speed system functioning in Podlaskie Voivodship. Transp. Probl. 2018, 13, 5-12. [CrossRef]

28. Pérez-Sansalvador, J.C.; Lakouari, N.; García-Díaz, J. Pomares Hernández, S.E. The effect of speed humps in instantaneous traffic emissions. Appl. Sci. 2020, 10, 1592. [CrossRef]

29. Torres, J.; Cloutier, M.S.; Bergeron, J.; St-Denis, A. They installed a speed bump: Children's perception of traffic calming measures around elementary schools. Child. Geogr. 2020, 18, 477-789. [CrossRef]

30. Pérez-Acebo, H.; Ziolkowski, R.; Linares-Unamunzaga, A.; Gonzalo-Orden, H. A series of vertical deflections, a promising calming measure: Analysis and Recommendations for Spacing. Appl. Sci. 2020, 10, 3368. [CrossRef]

31. Jasiuniene, V.; Cygas, D. Analysis of older pedestrian accidents: A case study of Lithuania. Balt. J. Road Bridge Eng. 2020, 15, 147-160. [CrossRef]

32. Petru, J.; Krivda, V. The transport of oversized cargoes from the perspective of sustainable transport infrastructure in cities. Sustainability 2021, 13, 5524. [CrossRef]

33. Almoshaogeh, M.; Abdulrehman, R.; Haider, H.; Alharbi, F.; Jamal, A.; Alarifi, S.; Shafiquzzaman, M. Traffic accident risk assessment framework in Qassim, Saudi Arabia: Evaluating the impact of speed cameras. Appl. Sci. 2021, 11, 6682. [CrossRef]

34. Szagala, P.; Olszewski, P.; Czajewski, W.; Dabkowski, P. Active signage of pedestrian crossing as a tool in road safety measurements. Sustainability 2021, 13, 9405. [CrossRef]

35. Obregón-Biosca, S.A. Speed humps and speed tables: Externalities on vehicle speed, pollutant emissions and fuel consumption. Results Eng. 2020, 5, 100089. [CrossRef]

36. Panis, L.I.; Broekx, D.; Becks, C. Impact of $30 \mathrm{~km} / \mathrm{h}$ Zone Introduction on Vehicle Exhaust Emissions in Urban Areas. In Proceedings of the European Transport Conference (ETC), Strasbourg, France, 18 September 2006.

37. Da Silva, F.N.; Custódio, R.A.L.; Martins, H. Low Emission Zone: Lisbon's Experience. J. Traffic Logist. Eng. 2014, 2, 133-139. [CrossRef]

38. De Vlieger, I.; De Keukeleere, D.; Kretzschmar, J. Environmental effects of driving behaviour and congestion related to passenger cars. Atmos. Environ. 2000, 34, 4649-4655. [CrossRef]

39. Liimatainen, H. Measures for Energy Efficient and Low Emission Private Mobility. In Affordable and Clean Energy. Encyclopedia of the UN Sustainable Development Goals; Filho, W.L., Azul, A.M., Brandli, L., Salvia, A.L., Wall, T., Eds.; Springer International Publishing: Cham, Switzerland, 2020; pp. 1-12. [CrossRef]

40. Tang, J.; McNabola, A.; Mistear, B. The potential impacts of different traffic management strategies on air pollution and public health for a more sustainable city: A modelling case study from Dublin, Ireland. Sustain. Cities Soc. 2020, 60, 102229. [CrossRef]

41. Beckx, C.; Panis, L.I.; De Vlieger, I.; Wets, G. Influence of Gear-Changing Behavior on Fuel Use and Vehicular Exhaust Emissions. In Highway and Urban Environment. Alliance for Global Sustainability Bookseries; Morrison, G.M., Rauch, S., Eds.; Springer: Dordrecht, The Netherlands, 2007; Volume 12. [CrossRef]

42. Wang, M.M.; Daamen, W.; Hoogendorrn, S.; Aren, B. Estimating acceleration, fuel consumption, and emissions from macroscopic traffic flow data. Transp. Res. Rec. 2011, 2260, 123-132. [CrossRef] 
43. Abdi, A.; Rad, H.B.; Azimi, E. Simulation and Analysis of Traffic Flow for Traffic Calming. Proc. Inst. Civ. Eng. Munic. Eng. 2017, 170, 16-28. [CrossRef]

44. Mackie, A.M.; Ward, H.A.; Walker, R.T. Urban Safety Project, Part 3: Overall Evaluation of Area Wide Schemes; TRRL Report 263; Transport and Road Research Laboratory: Crowthorne, UK, 1990.

45. Sołowczuk, A.; Kacprzak, D. Identification of the determinants of the effectiveness of on-road chicanes in transition zones to villages subject to a $70 \mathrm{~km} / \mathrm{h}$ speed limit. Energies 2020, 13, 5244. [CrossRef]

46. Solowczuk, A.B.; Kacprzak, D. Identification of the determinants of the effectiveness of on-road chicanes in the village transitition zones subject to a $50 \mathrm{~km} / \mathrm{h}$ speed limit. Energies 2021, 14, 4002. [CrossRef]

47. Urban Traffic Areas-Part 7-Speed Reducers; Vejdirektoratet-Vejregeludvalget: Copenhagen, Denmark, 1991.

48. Traffic Calming Guidelines; Devon County Council Engineering \& Planning Department: Devon, UK, 1992.

49. Sayer, I.A.; Parry, D.I. Speed Control Using Chicanes-A Trial at TRL; TRL Project Report PR 102; Transport Research Laboratory: Crowthorne, UK, 1994.

50. Sayer, I.A.; Parry, D.I.; Barker, J.K. Traffic Calming-An Assessment of Selected On-Road Chicane Schemes TRL Report 313; Transport Research Laboratory: Crowthorne, UK, 1998.

51. Crevier, C. Les Aménagements en Modération de la Circulation, Étude et Applications; École de Technologie Supérieure Université Du Québec: Montréal, QC, Canada, 2007.

52. Directives for the Design of Urban Roads. RASt 06 Road and Transportation Research Association; Working Group Highway Design FGSV: Köln, Germany, 2006.

53. Safe Road Design Manual. Amendments to the WB Manual; Transport Rehabilitation Project ID PO75207; Consulting Services for Safe Road Design: Loan, Sweden, 2011.

54. Hernández, E.; Abadía, X.; París, A.C. Criterios de Movilidad ZONAS 30; Fundación RACC: Barcelona, Spain, 2007.

55. Guidelines for Traffic Calming; City of Sparks, Public Works; Traffic Division: Reno, NV, USA, 2007.

56. Berger, W.J.; Linauer, M. Speed Reduction at City Limits by Using Raised Traffic Islands; Institut fuer Verkehrswesen (Institute for Transport Studies), Universitaet fuer Bodenkultur A-1190: Vienna, Austria, 1998.

57. Prato, C.G.; Rasmussen, T.K.; Kaplan, S. Risk Factors Associated with Crash Severity on Low-Volume Rural Roads in Denmark. J. Transp. Saf. Secur. 2014, 6, 1-20. [CrossRef]

58. Vahl, H.G.; Giskes, J. Traffic Calming through Integrated Urban Planning; Amarcande: Paris, France, 1990.

59. Seneci, F.; Avesani, F.; Bonomi, I. Piani Particolareggiati per Mobilita' Ciclabile e Pedonale e Sicurezza Stradale; Comune di Bassano del Grappa: Verona, Italy, 2012.

60. Sadeghi-Bazargani, H.; Saadati, M. Speed Management Strategies; A Systematic Review. Bull. Emerg. Trauma 2016, 4, 126-133. [PubMed]

61. González, D.D. Evaluación de las Zonas 30 en Europa y Definición de una Zona 30 Revisada. Ph.D. Thesis, Universitat Politècnica de Catalunya, Barcelona, Spain, 2012.

62. Bahar, G.B. Guidelines for the Design and Application of Speed Humps; Institute of Transportation Engineers: Washington, DC, USA, 2007.

63. Hallmark, S.L.; Peterson, E.; Fitzsimmons, E.; Hawkins, N.; Resler, J.; Welch, T. Evaluation of Gateway and Low-Cost Traffic-Calming Treatments for Major Routes in Small Rural Communities; Institute for Transportation, Iowa State University: Ames, IA, USA, 2007.

64. Ellebjerg, L. Noise Control through Traffic Flow Measures-Effect and Benefits; Raport 151; Danish Road Institute: Hedehusene, Denmark, 2007.

65. Daniels, S.; Martensen, H.; Schoeters, A.; Van de Berghe, W.; Papadimitrou, E.; Ziakopoulos, A.; Kaiser, S.; Aigner-Breuss, E.; Soteropoulos, A.; Wijnen, W.; et al. A systematic cost-benefit analysis of 29 road safety measures. Accid. Anal. Prev. 2019, 133, 105292. [CrossRef]

66. Gonzalo-Orden, H.; Pérez-Acebo, H.; Unamunzagas, A.L.; Arce, M.R. Effects of traffic calming measures in different urban areas. Transp. Res. Proc. 2018, 33, 83-90. [CrossRef]

67. Pérez-Acebo, H.; Otxoa-Muñoz, X.; Marquina-Llaguno, M.; Gonzalo-Orden, H. Analysis of the efficiency of traffic lights turning red in case of exceeding speed limit. Ing. Investig. 2021, 41, e86047. [CrossRef]

68. Pérez-Acebo, H.; Otxoa-Muñoz, X.; Marquina-Llaguno, M.; Gonzalo-Orden, H. Evaluation of the Efficiency of Traffic Lights Turning Red in Case of Exceeding Speed Limit with Previous Panels Indicating the Speed. In Proceedings of the XIV Congreso de Ingenieria del Transporte (CIT 2021), University of Burgos, Burgos, Spain, 6-8 July 2021; pp. 2987-2999. [CrossRef]

69. Hernández, H.; Alberdi, E.; Pérez-Acebo, H.; Álvarez, I.; García, M.J.; Eguía, E.; Fernández, K. Managing traffic data through clustering and radial basis functions. Sustainability 2021, 13, 2846. [CrossRef]

70. Pérez-Acebo, H.; Gonzalo-Orden, H.; Findley, D.J.; Rojí, E. Modeling the international roughness index performance on semi-rigid pavements in single carriageway roads. Constr. Build. Mater. 2021, 272, 121665. [CrossRef]

71. Diputación Foral de Bizkaia. Evolución del Tráfico en las Carreteras de Bizkaia-Trafikoaren Bilakaera Bizkaiko Errepideetan 2018; Departamento de Desarrollo Económico y Territorial: Bilbao, Spain, 2020.

72. Diputación Foral de Álava. Estudio de Tráfico. 2018. Red de Carreteras del Territorio Histórico de Álava-2018. Trafiko Azterketa. Arabako Lurralde Historikoaren Errepide-Sarea; Departamento de Infraestructuras Viarias y Movilidad: Vitoria-Gasteiz, Spain, 2020. 
73. Ziółkowski, R. Speed Profile as a tool to estimate traffic calming measures efficiency. J. Civ. Eng. Archit. 2014, 8, 1585-1592.

74. Ziółkowski, R. Influence of Traffic Calming Measures on Drivers' Behaviour. In 9th International Conference Environmental Engineering: Selected Papers; Vilnius Gediminas Technical University Press Technika: Vilnius, Lithuania, 2014. [CrossRef]

75. Ziółkowski, R. Effectiveness of Automatic Section Speed Control System Operating on National Roads in Poland. Promet-Traffic Transp. 2019, 31, 435-442. [CrossRef] 